\title{
PENGARUH SISTEM INFORMASI MANAJEMEN TERHADAP PENGELOLAAN SEKOLAH
}

\author{
Putri Ramadhani \\ 17002026 \\ Email atiputrirmd99@gmail.com
}

\begin{abstract}
Setiap sekolah pasti memiliki suatu manajemen dalam melakukan pengelolaan sekolah, dengan adanya hal ini sekolah memerlukan sistem informasi manajemen untuk mempermudah setiap sekolah melakukan manajemen sekolah dengan baik dan cepat sehingga hal ini dapat menghemat waktu dan tenaga untuk melakukan manajemen pengelolaan sekolah. Tujuan dari penelitian in ialah untuk mengetahui bagaimana pengaruh penggunaan sistem informasi manajemen terhadap pengelolaan sekolah dan apa jadinya sekolah jika tidak adanya sistem informasi manajemen di sekolah. Penelitian ini menggunakan metode studi literatur yaitu mengumpulkan sumber yang ada seperti dari jurnal, buku-buku, dan bahan bacaab lainnya. Sistem informasi manajemen sangat dibutuhkan dalam pengelolaan seklah terutma dalam proses pengambilan keputusan.
\end{abstract}

Kata kunci : sistem informasi manajemen, pengelolaan sekolah, pengambilan keputusan

\section{LATAR BELAKANG}

Pengelolaan sekolah merupakan suatu kegiatan yang dilakukan untuk meningkatkan kinerja sekolah dengan cara melakukan manajemen yang baik terhadap sekolah untuk mencapai tujuan pendidikan yang telah ditetapkan sebelumnya. Dalam melakukan pengelolaan sekolah di perlukan adanya manajemen sekeolah. Dimana dengan adanya manajemen sekolah ini maka setiap sekolah dapat melakukan pekerjaannya dengan baik dan mencapai tujuan bersama. Dalam melakukan manajemen sekolah diperlukan adanya sistem yang mendukung dengan adanya sistem ini maka kerja sekolah menjadi tetarget, untuk itu diperlukan sistem informasi manajemen dalam melakukan kegiatan pengelolaan sekolah. Menurut Ahmad Sabandi dalam jurnalnya (Sabandi, 2019) sistem informasi manajemen merupakan suatu metode dalam menghasilkan metode imformasi yang tepat waktu terhadap 
manajemen, bertujuan untuk proses pengambilan keputusan dan memperbaiki proses perencanaan dan pengwasan suatu lembaga.

\section{PEMBAHASAN}

Dalam melakukan pengelolaan sekolah pasti diperlukannya sebuah manajemen sekolah, dimana manajemen sekolah ini merupakan kegiatan yang dilakukan dalam mengatur, mengelola kegiatan sekolah yang ada. Dengan adanya manajemen sekolah kepala sekolah akan merasa mudah dalam melakukan kegiatan pengelolaan sekolah. Seiring berkembangnya zaman manajemen sekolah memerlukan yang namany sistem. Dimana sistem ini bertujuan untuk melakukan manajemen sekolah dengan cepat sehingga pengelolaan sekolah menjadi efektif dan efisien. Sistem ini disebut dengan istilah sistem informasi manajemen. Sistem informasi manajemen bertujuan untuk membantu sekolah dalam proses pengambilan keputusan. Sehingga hal ini dapat menhemat waktu, tenaga, dan fikiran. Karena sekolah dibantu oleh sebuah aplikasi yang menyediakan data-data sekolah, hal ini dapat memudahakan sekolah dalam pengambilan keputusan untuk kemajuan sekolah kedepannya.

Menurut Siti Nur Elia Lailasari dalam jurnalnya (Nur, 2017) menyatakan bahwa sistem informasi manajemen dapat dijadikan alternatif pilihan dalam meningkatkan kualitas suatu Lembaga pendidikan. Kualitas lembaga pendidikan dapat dilihat dari kualitas sumber daya manusia yang ada pada suatu sekolah. Apabila sumber daya manusia yang ada dilingkungan sekolah tersebut memiliki kualitas yang baik maka kulitas sekolah akan menjadi baik juga. Dengan adanya sistem informasi manajemen sumber daya manusia juga dapat dibentuk dengan baik. Menurut Tri Firmansyah dkk dalam jurnalnya (Firmansyah, 2017) berpendapat bahwa sistem informasi manajemen memiliki peran dalam meningkat kualitas guru disekolah karena dengan adanya sisttem informasi manajemen dapat mempercepat guru dalam menyampaikan materi pembelajaran ke siswa serta dapat mempercepat guru untuk membuat laporan siswa. Sehingga hal ini dapat menghemat waktu dan tenaga guru.

Tujuan dari sistem informasi manajemen diataranya :

- Memudahakan sekolah dalam melakukan kegiatan pengolahan data.

- Menghamat waktu dalam melakukan kegiatan pengumpuan informasi.

- Membantu dalam melakukan proses pengambilan keputusan.

- Mempermudah pekerjaan guru dalam membuat laporan siswa.

- Membantu kepala sekolah dalam menganalisis data-data sekolah untuk menentukan kebijkan apa yang bagus dilakukan kedepannya untuk kemjuan sekolah.

- Dapat membantu sekolah dalam melakukan promosi sekolah.

- Memudahkan sekolah untuk mengakses informasi luar yang digunakan untuk kemajuan sekolah. 
Dengan adanya hal ini sekolah dapat terbantu dalam meningkatkan kualitas sekolah. Sistem informasi manajemen juga dapat membantu dalam mengolah data-data sekolah sehingga tidak memerlukan banyak waktu dalam melakukan pengolahan data. Dengan hal ini sekolah dapat menhemat waktu, tenaga dan biaya sekolah.

Pada saat sekarang ini sangatlah dibutuhkan proses informasi yang cepat dalam melakukan sebuah kegiatan, untuk itu sistem informasi manajemen sangat penting digunakan di sekolah. Karena setiap sekolah pasti memiliki data-data yang banyak yang perlu di olah untuk kebutuhan sekolah. sistem informasi manajemen dapat membantu para administrator sekolah dalam melakukan kegiatan pengolahan data sekolah. selain itu ssitem informasi manajemen juga berguna untuk melakukan pengambilan keputusan terhadap kemajuan sekolah kedepannya. Kalua sistem informasi manajemen ini dapat digunakan dengan baik hal ini daapt menunjang keberhasilan sekolah dalam meningkatkan kualitas sekolah.

Pengelolaan sekolah juga menjadi hal penting yang perlu diperhatikan dalam lembaga pendidikan. Dengan adanya pengelolaan sekolah yang baik maka akan nama baik sekolah juga akan menjadi bagus terhadap pihak luar seklah. Dan hal ini dapat menjadikan sekolah dipercayai oleh pihak-pihak luar sekolah. lulusan yang dihasilkan dari sekolah pun pasti akan menjadi lulusan yang baik dan kualitasnya pun akan bagus. Hal inilah yang menjadi tujuaan utama dari Lembaga pendidikan. Karena itu sistem informasi manajemen sangatlah penting digunakan di setiap sekolah. 


\section{KESIMPULAN}

Dengan adanya sistem informasi manajemen dapat membantu sekolah dalam melakukan pengelolaan sekolah terutama dama melakukan analisis data untuk pengambilan keputusan. Sistem informasi manajemen membantu sekolah dalam mencari alternatif-alternatif yang akan dipilih dalam proses pengambilan keputusan. Jika keputusan yang diambil selalu tepat maka kualitas sekolah pun pasti akan meningkat dan pengelolaan sekolah akan berjalan dengan sefektif dan efisisien,

Dalam melakukan pengelolaan sekolah setiap sumber daya yang manusia yang ada harus ikut berperan aktif dalam meningkatkan kualitas sekolah. Jika hanya kepala sekolah saja yang bergerak maka sekolah tidak akan dapat mencapai tujuaan pendidikan. Dengan adanya sistem informasi manajemen dapat membantu sekolah dalam melakukan langkah-langkah terbaik untuk memajukan sekolah kedepannya.

\section{SARAN}

Dengan adanya sistem informasi manajemen ini diharapkan setisp sekolah dapat memanfaatkannya dengan baik, karena hal ini sangat membantu sekolah dalam meningkaykan kualitas sekolah tersebut. Dan setiap sekolah haruslah mengikuti perkembangan zaman agar sekolah tersebut tidak tertinggal dan dapat meningkatkan kualitas sekolah sesuai dengan perkembangan zaman. 


\section{DAFTAR RUJUKAN}

Firmansyah, tri dkk. (2017). HUBUNGAN PENGELOLAAN SISTEM INFORMASI MANAJEMEN DENGAN PRODUKTIFITAS GURU SMK. Jurnal Teknologi, 8(2), 101-108.

Nur, S. (2017). SISTEM INFORMASI MANAJEMEN SEKOLAH DAN BUDAYA SEKOLAH TERHADAP KEPUASAN SISWA SMAN DI KOTA BANDUNG. Jurnal Pendidikan, 2(2), 2-3.

Sabandi, A. (2019). PERSEPSI GURU DALAM MENINGKATKAN MUTU PENDIDIKAN BERBASIS SISTEM INFORMASI MANAJEMEN DI SEKOLAH DASAR NEGERI 08 BATANG ANAI. Jurnal Administrasi Pendidikan, 2(5), 1-7. 